\title{
Assessment of the Haematological Profile After Appendectomy Using Linear Titanium Stapler Clips: an Experimental Study in Rats
}

\author{
Amela Bajrić, ${ }^{1}$ Muhamed Katica, ${ }^{2}$ Aida Katica, ${ }^{3}$ Alisa Smajović, ${ }^{4}$ Mujo Sivić, ${ }^{1}$ \\ Dunja Rukavina, ${ }^{5}$ Mirza Čelebićić, ${ }^{6}$ Amir Zahirović, ${ }^{7}$ Ajla Bajrić, ${ }^{8}$ Samir Delibegović ${ }^{9}$
}

\section{Abstract}

Introduction: The technique of closing the appendiceal stump using linear titanium stapler clips is being used more and more frequently in laparoscopic surgery, despite the good practice in the use of resorbable single endoloop vicryl ligatures and/or the non-resorbable plastic hem-o-lok clips. No light has been shed on potential undesirable effects on the haemathological profile of the use of titanium stapler clips. This experimental study aimed at establishing any possible undesirable effect of linear titanium stapler clips and single resorbable vicryl endoloop ligatures on the blood cells in rats following appendectomy.

Methods: A total of 70 adult rats were used, divided into a control group ( $\mathrm{n}=10$ ), and two experimental groups $(n=30+30)$. The appendices were removed from the rats in the first experimental group using titanium stapler clips and in the second experimental group the appendiceal stump using resorbable endoloop vicryl ligatures was closed. In both experimental groups three sub-groups with ten animals each were formed, from which peripheral blood from a tail vein on days 7, 28 and 60 was removed postoperatively, in order to assess the usual haematological parameters. Stained blood smears were also analysed in order to establish any poikilocytotic erythrocytes present.

Results: In the first experimental group, with the titanium stapler clips, more than $25 \%$ neutrophils were found on day 7, which is a significantly different result (p $<0.05$ ) to the control group. In the second experimental group, there were more neutrophils than in the titanium stapler clips group, especially on days 7 and 60 and the results of these two sub-groups differ statistically significantly, $\mathrm{p}<0.05$. Hypochromia was found in the endoloop vicryl ligatures group, as well as in the titanium stapler clips sub-group on day 28, due to lower haemoglobin values which were significantly different to the control group, $p<0.05$. Moderate levels of annulocytes, spherocytes and stomatocytes were found in most experimental groups. Conclusion: The results of this study favour the use of linear titanium stapler clips over resorbable single endoloop vicryl ligatures, because a less unfavourable effect was established on the blood cells of the experimental rats with their use.

Keywords: Appendectomy; Titanium stapler clips; Annulocytes; Neutrophils; Hypochromia.
(1) Cantonal Hospital "Dr Irfan Ljubljankić", Bihać, Bosnia and Herzegovina.

(2) Department of Pathological Physiology, Veterinary Faculty, University of Sarajevo, Sarajevo, Bosnia and Herzegovina.

(3) Senior student, Veterinary Faculty, University of Sarajevo, Sarajevo, Bosnia and Herzegovina.

(4) Department of pharmaceutical informatics and pharmacoeconomics, Faculty of Pharmacy, University of Sarajevo, Sarajevo, Bosnia and Herzegovina.

(5) Department of Biology, Veterinary Faculty, University of Sarajevo, Sarajevo, Bosnia and Herzegovina.

(6) Faculty of Science, University of Sarajevo, Sarajevo, Bosnia and Herzegovina.

(7) Department of Internal Disease, Veterinary Faculty, University of Sarajevo, Sarajevo, Bosnia and Herzegovina.

(8) Senior student, Faculty of Medicine, University of Banja Luka, Banja Luka, Bosnia and Herzegovina.

Surgery Clinic, University Clinical

(9) Center Tuzla, Tuzla, Bosnia and Herzegovina.

Correspondence:

AMELA BAJRIĆ

T: +387 37318800

E: amelabajricdr@gmail.com

\section{ARTICLE INFO}

Received: 9 December 2020 Revision received: 12 March 2021 Accepted: 15 March 2021

\section{Introduction}

Laparoscopic appendectomy as a surgical technique for dealing with the appendix, has wide- spread use in abdominal surgery, and its roots go back to the 1980 's. ${ }^{1}$

Copyright $\odot 2021$ Bajić et al. This is an open access article distributed under the Creative Commons Attribution License (CC BY), which permits unrestricted use, distribution, and reproduction in any medium, provided the original work is properly cited. This article should be cited as follows: Bajić A, Katica M, Katica A, Smajović A, Sivić M, Rukavina D, et al. Assessment of the haematological profile after appendectomy using linear titanium stapler clips: an experimental study in rats. Scr Med 2021 Mar;52(1):22-7. 
The most frequently used technique for closing the appendiceal stump is the single endoloop ligature, ${ }^{2,3}$ whilst non-resorbable polymer plastic clips are an alternative technique used to close the appendiceal stump more quickly and cheaply than standard methods. ${ }^{1}$ In contrast to these, titanium stapler clips may also be used successfully to treat all forms of acute appendicitis. ${ }^{4}$

The effects on the tissue and organism in general caused by this laparoscopic method have not yet been fully discussed. Differences between the degree of inflammation and the foreign body reaction to different materials used in laparoscopic appendectomy favour the use of titanium stapler clips. $^{5-7}$

The fact is that the development of various diagnostic scores, ${ }^{8}$ and the mass use of diagnostic aids, for example C-reactive protein, ${ }^{9}$ have often been the cause of confused diagnoses made by a large number of clinicians. ${ }^{10}$ Practically no laboratory or radiological test is $100 \%$ accurate. ${ }^{11}$ As a result it is important to compare these tests and monitor the haematological parameters. Kamaran et al $(2008)^{12}$ mention the importance of analysing the total leukocyte count in patients in whom appendectomy is indicated.

There are reports whose results indicate monitoring local inflammatory responses. ${ }^{2,7,13,14}$ Reports describing changes in haematological parameters in the peripheral blood in the post-operative period in treated patients are few. As a result, little is known about how non-resorbable linear titanium stapler clips affect blood cells after appendectomy.

Monitoring haematological parameters, not only in cells of the leukocyte order, but also all other closely related parameters, for example in relation to erythrocytes in the post-operative period, is also extremely important for the successful post-operative care of patients.

\section{The Aim of the Study}

The aim of this experimental study was to establish any possible, undesirable effect of linear titanium stapler clips and single resorbable endoloop vicryl ligatures on the blood cells of experimental rats.

\section{Methods}

\section{Approval by the Ethics Committee}

This research was approved by the Ethics Committee for the Protection and Welfare of Experimental Animals in Biomedical Research of the Faculty of Medicine, University of Banja Luka No 18/2/20.

\section{Study Design and Animals}

The experimental study was conducted on an animal model using albino Wistar rats. A total of 70 adult rats were used, weighing 250-300 g. The animals were kept in polypropilene cages under optimal conditions: temperature $22 \pm 2{ }^{\circ} \mathrm{C}$, relative humidity $43 \%$ to $67 \%$, and a light:dark cycle of 12:12 hours. The rats consumed briquette food and drinking water ad libitum. Twenty-four hours before the surgery, the animals were denied food.

The rats were divided into three groups: the control $(\mathrm{n}=10)$, which did not undergo appendectomy, and two experimental groups. The animals in the first experimental group $(1, \mathrm{n}=30)$ had their appendix removed, with the use of non-resorbable titanium stapler clips. In the second experimental group $(2, n=30)$, the appendiceal stump was closed off with resorbable endoloop vicryl ligatures. In both experimental groups, three sub-groups were formed, with ten animals each, from which the peripheral blood was removed on days 7,28 and 60.

\section{Surgical Procedures}

Ketamine hydrochloride $(50 \mathrm{mg} / \mathrm{kg}$ ) (International B.V. Boxmeer, The Netherlands) was used, as the general anaesthetic, intramuscularly. The rats earmarked for surgery were previously prepared by shaving the fur in the abdominal region. The skin was then disinfected with a povidon-iodine solution. The animals were fixed to the operating table in a supine position. The laparotomy was performed using a medial incision. After the caecum was located, a large sac in the lower third of the abdominal cavity which mimics the appendix in humans, it was resected.

The rats in the control group $(n=10)$ did not undergo surgery. The rats in the first experimental group, $1(\mathrm{n}=30)$ had their appendix removed using non-resorbable linear $45 \mathrm{~mm}$ titanium stapler clips, (thick filling) (Ethicon, Endosurgery, Cincinnati, $\mathrm{OH})$. In group $2(\mathrm{n}=30)$ the blind-end 
of the appendix (about $0.7 \mathrm{~cm}$ long) was closed with a Vicryl 2-0 ligature (Vicryl Ethicon, polyglactin 910). The laparotomy and closure were performed with a continuous suture of 3-0. During the surgical procedure and in the post-operative period no antibiotic therapy was used.

\section{Haematological Procedure}

Ten animals from experimental groups had peripheral blood drawn from the caudal vein three times: on the 7th, 28th and 60th postoperative days. Rats from the control group $(n=10)$ had blood drawn only once, and it was used for comparison. Using an "Idexx Laser Cyte" flow haemocytometer, results were obtained for: haemoglobin $(\mathrm{Hb})(\mathrm{g} / \mathrm{dL})$, haematocrits (HCT) (\%), Mean Corpuscular Volume (MCV) (fL), Mean Corpuscular Haemoglobin (MCH) (pg), Mean Corpuscular Haemoglobin Concentration (MCHC) (g/dL), total erythrocyte count (RBC) $\left(10^{12} / \mathrm{L}\right)$ and total leukocyte count (WBC) $\left(10^{9} / \mathrm{L}\right)$.

\section{Microscopic Examination of Peripheral Blood}

Samples of peripheral blood were collected from the vena caudalis with the intention of creating at least two sample blood smears, using the standard Giemsa laboratory staining procedure. Analysis of the stained blood smears was based on the standard morphology and performed by two independent researchers. Differentiation and percentage expression of the blood cells observed were conducted on a sample, with a single layer field of vision, where only the edges of the the blood cells touched one another, and they did not overlap. ${ }^{15}$

The poikilocytotic erythrocytes were classified semi-quantitatively according to similar research, ${ }^{16}$ following the criteria: non-existent (0\%), scarce $(0.05-0.5 \%)$, mild ( $>0.5-3 \%)$, moderate ( $>3 \%-10 \%$ ), or strongly expressed (> $10 \%$ ). The number and type of poikilocytotics were noted as a percentage of the RBC.

For each original stained smear, 1000 erythrocytes were counted and analysed, using a binocular light microscope, Motic Type $102 \mathrm{M}$, with $900 \mathrm{x}$ magnification. The average values from two independent researchers, that is, two sets of measurements were taken.

Lymphocytes (L) (\%), neutrophils (N) (\%), monocytes (M) (\%), basophils (B) (\%) and eosinophils (E) (\%), were differentiated according to similar studies $^{3,17}$ and are shown as percentages after analysis of 1000 cells of the leukocyte order, for each blood smear sample in the experimental and control groups, also using a Motic Type $102 \mathrm{M}$ binocular light microscope, with $900 \mathrm{x}$ magnification.

\section{Statistical data analysis}

For statistical data processing the IBM program SPSS Statistics for Windows, Version 24 was used. Data processing was performed using the ANOVA / Kruskal Wallis test (depending on whether the data were normally distributed - the Shapiro-Wilk test was used to examine normality), and $\mathrm{p}<0.05$ was considered statistically significant. ${ }^{18}$

\section{Results}

After statistical processing of the data, it was established that a statistically significant difference existed in almost all the tested parameters in the experimental groups in comparison with the control (Graph 1 and Table 1). The RBC values did not change significantly in all three endoloop vicryl ligatures subgroups, but there were differences in the titanium stapler clips groups on days 7 and 60 in comparison with the control. It was similar with the HCT values, where Table 1 shows that there were no differences between the endoloop vicryl ligatures sub-groups, but there was a difference in the stapler group on day 60 in comparison with the control. The values of the parameters $\mathrm{HB}, \mathrm{MCV}$ and MCHC changed statistically significantly in comparison with the control in all three experimental vicryl sub-groups, whilst in the first experimental titanium stapler clips group, HB was $<0.05$ on day 28 , MCV in the stapler groups on days 28 and 60 .

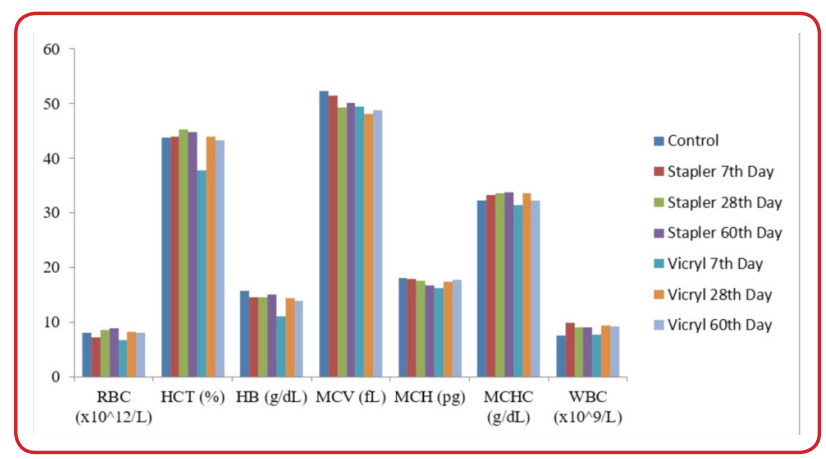

Figure 1. Haematological parameters in the experimental stapler and vicryl groups, and the control group 
Table 1: Statistical analysis of haematological parameters

\begin{tabular}{|c|c|c|c|c|c|c|}
\hline \multirow[b]{3}{*}{$\begin{array}{l}\text { Haematological } \\
\text { parameters }\end{array}$} & \multicolumn{6}{|c|}{$p$ value } \\
\hline & \multicolumn{3}{|c|}{ Group I } & \multicolumn{3}{|c|}{ Group II } \\
\hline & $\begin{array}{l}\text { Stapler } \\
7^{\text {"n Day }}\end{array}$ & $\begin{array}{l}\text { Stapler } \\
28^{\text {In Day }}\end{array}$ & $\begin{array}{l}\text { Stapler } \\
60^{\mathrm{n}} \text { Day }\end{array}$ & $\begin{array}{l}\text { Vicryl } \\
7^{\mathrm{h}} \text { Day }\end{array}$ & $\begin{array}{c}\text { Vicryl } \\
28^{\text {th }} \text { Day }\end{array}$ & $\begin{array}{c}\text { Vicryl } \\
60^{\text {nt Day }}\end{array}$ \\
\hline $\mathrm{RBC}\left(\times 10^{12} / \mathrm{L}\right)$ & 0.011 & 0.113 & 0.002 & 0.161 & 0.243 & 0.604 \\
\hline HCT (\%) & 0.531 & 0.153 & 0.028 & 0.085 & 0.870 & 0.870 \\
\hline $\mathrm{HB}(\mathrm{g} / \mathrm{dL})$ & 0.06 & 0.05 & 0.306 & 0.000 & 0.022 & 0.004 \\
\hline MCV (fL) & 0.700 & 0.001 & 0.024 & 0.004 & 0.000 & 0.003 \\
\hline $\mathrm{MCH}(\mathrm{pg})$ & - & & & - & - & - \\
\hline $\mathrm{MCHC}(\mathrm{g} / \mathrm{dL})$ & 0.015 & 0.004 & 0.000 & 0.001 & 0.002 & 0.01 \\
\hline WBC (x 109/L) & & & & - & - & - \\
\hline
\end{tabular}

A significant difference was found in the titanium stapler clips sub-group on day 7 in relation to the control group for the parameters N, L, M. For the stapler sub-group, on day 60 significant differences were noticed for the $\mathrm{L}$ and $\mathrm{M}$ results. In the stapler sub-group, no statistically significant difference was noticed on day 28 in comparison with the control group for any parameters (Figure 2 and Table 2).

In the endoloop vicryl ligatures sub-group, none of the parameters showed any statistically significant difference in comparison with the control on day 28, whilst in the vicryl groups on days 7 and 60 the differences in the values of $\mathrm{N}$ and $\mathrm{L}$ were $\mathrm{p}<0.05$ (Figure 2 and Table 2).

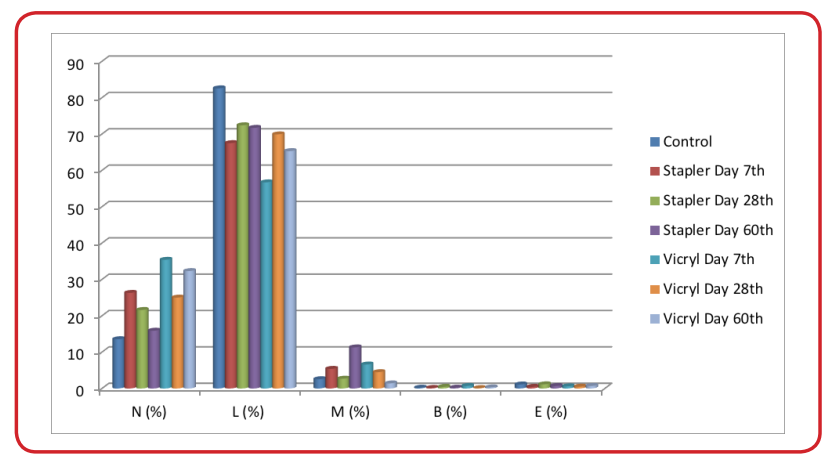

Figure 2. Leukogram results (\%) of the experimental and control groups

Table 2: Statistical analysis of the control group in relation to the experimental groups in relation to the leukogram

\begin{tabular}{|c|c|c|c|c|c|c|}
\hline \multirow[b]{3}{*}{$\begin{array}{l}\text { Leukocyte } \\
\text { cells }\end{array}$} & \multicolumn{6}{|c|}{$p$ value } \\
\hline & \multicolumn{3}{|c|}{ Group I } & \multicolumn{3}{|c|}{ Group II } \\
\hline & $\begin{array}{l}\text { Stapler } \\
\text { Day } 7\end{array}$ & $\begin{array}{l}\text { Stapler } \\
\text { Day } 28\end{array}$ & $\begin{array}{l}\text { Stapler } \\
\text { Day } 60\end{array}$ & $\begin{array}{l}\text { Vicryl } \\
\text { Day } 7\end{array}$ & $\begin{array}{l}\text { Vicryl } \\
\text { Day } 28\end{array}$ & $\begin{array}{c}\text { Vicryl } \\
\text { Day 60 }\end{array}$ \\
\hline Neutrophils & 0.01 & 0.22 & 0.412 & 0.001 & 0.172 & 0.006 \\
\hline Lymphocytes & 0.001 & 0.164 & 0.01 & 0.000 & 0.104 & 0.013 \\
\hline Monocytes & 0.021 & 0.901 & 0.000 & 0.063 & 0.662 & 0.946 \\
\hline Basophils & - & - & - & - & - & - \\
\hline Eosinophils & 0.055 & 0.965 & 0.233 & 0.065 & 0.075 & 0.259 \\
\hline
\end{tabular}

Table 3: The average values of the poikilocytotic forms per 1000 erythrocytes

\begin{tabular}{|c|c|c|c|c|c|c|c|}
\hline $\begin{array}{l}\text { Poikilocytotic } \\
\text { forms of } \\
\text { erythrocytes }\end{array}$ & Follow-up & $\begin{array}{c}\text { Stapler } \\
\text { Day } 7\end{array}$ & $\begin{array}{l}\text { Stapler } \\
\text { Day } 28\end{array}$ & $\begin{array}{l}\text { Stapler } \\
\text { Day } 60\end{array}$ & $\begin{array}{l}\text { Vicryl } \\
\text { Day } 7\end{array}$ & $\begin{array}{c}\text { Vicryl } \\
\text { Day } 28\end{array}$ & $\begin{array}{c}\text { Vicryl } \\
\text { Day } 60\end{array}$ \\
\hline OVALOCYTES & 0.195 & 1.4 & 0.52 & 0.485 & 0.49 & 0.485 & 0.795 \\
\hline DACRYOCYTES & 0.16 & 0.63 & 0.445 & 1.985 & 1.11 & 0.535 & 1.055 \\
\hline ANNULOCYTES & 1.025 & 6.59 & 5.16 & 4.23 & 3.445 & 4.56 & 5.14 \\
\hline ECHINOCYTES & 0.495 & 0.075 & 0.575 & 0.02 & 1.085 & 1.46 & 0.67 \\
\hline STOMATOCYTES & 0.27 & 1.005 & 1.735 & 7.785 & 0.5 & 1.765 & 0.635 \\
\hline DREPANOCYTES & 0 & 0.04 & 0.035 & 0.545 & 0.02 & 0 & 0.115 \\
\hline SCHISTOCYTES & 0.035 & 0.11 & 0.095 & 0.035 & 0.135 & 0.08 & 0.085 \\
\hline TARGET CELLS & 0 & 2.56 & 0.885 & 0.025 & 3.735 & 0.815 & 7.725 \\
\hline ACANTHOCYTES & 0 & 0.02 & 0.235 & 0.03 & 3.03 & 0 & 10.135 \\
\hline SPHEROCYTES & 0.01 & 4.92 & 1.63 & 1.805 & 2.56 & 1.565 & 12.48 \\
\hline RETICULOCYTES & 0.24 & 0.75 & 0.05 & 0.39 & 0.635 & 0.115 & 0.01 \\
\hline
\end{tabular}

Red colour indicates results with moderate (> $3 \%-10 \%)$, and strong (> $10 \%)$ values

If the appearance of poikilocytotic forms (Table 3 ) is considered, it may be seen that in all the experimental groups there is a moderate number of annulocytes, in the stapler sub-group on day 60 there is moderate stomatocytosis, whilst moderate spherocytosis appears in the titanium stapler clips sub-group on day 7. In the experimental endoloop vicryl ligatures group, there was strong acanthocytosis and spherocytosis in the vicryl subgroup on day 60, and moderate values for target cells in the endoloop vicryl ligatures sub-groups on days 7 and 60 . All the other poikilocytotic forms were mildly expressed (0.05 - $3 \%)$ within all the experimental groups.

\section{Discussion}

The tissue of the small and large intestines reacts to sutures and clips, as to any other foreign body. It has been established that non-resorbable linear titanium stapler clips cause less reaction in the surrounding tissue than resorbable endoloop vicryl ligatures. ${ }^{2,14,19}$ The results of the leukogram in this study completely correspond with the results of these researchers. In the first experimental group, titanium stapler clips, more than $25 \%$ neutrophils were found, on day 7, which is a significantly different result in comparison with the control group. The appearance of neutrophils is the expected reaction in the peripheral blood to the titanium stapler clips used to close the appendiceal stump. In the sub-groups of rats that underwent appendectomy where titanium stapler clips were used, mild neutrophilia was noticed on day 28 , whilst the neutrophils retur- 
ned to normal values on day 60 , and their percentage values were equal to the values in the control group. In the second experimental group, there were more neutrophils than in the titanium stapler clips group, especially on days 7 and 60, and the results of these two sub-groups differ statistically significantly to the results in the control group. If these results are compared with similar research, appendectomy using plastic hem-o-lok clips and the accompanying effects in the peripheral blood, by Bajrić et al (2020), ${ }^{3}$ it can be seen that the presented results partially correspond with theirs. In this study, neutrophilia, mild and expected monocytosis, was established in the vicryl sub-group on day 28 , and also in the titanium stapler clips sub-group on day 60 , which is a statistically significant result in comparison with the control group.

The results obtained regarding the total number of WBC are within the physiological reference intervals but tend towards the lower physiological level. The trend of lower values in the present study continues for lymphocytes, which were the most numerous cells in terms of percentage in the leukogram of the rats. The lowest physiological limit of lymphocytes in adult rates is $75 \%,{ }^{20}$ and the results obtained from both experimental groups in this study were slightly below this low physiological limit. The percentage of lymphocytes in the leukogram of the experimental animals differs significantly from the control group at all time periods in both experimental groups, except within the sub-groups on day 28.

The obvious mild lymphopenia in this case completely corresponds with the similar research by Bajrić et al (2020) ${ }^{3}$ for appendectomy using hemo-lok plastic clips. The reasons for the appearance of lymphopenia have not been completely explained and could possibly be linked to the stressful circumstances for the experimental rats during the appendectomy, as well as the possible effect of the anaesthetic, as iatrogenic factors.

Lower percentage values of basophils and eosinophils were found, appropriate to their physiological reference ranges, and they were in line with relatively similar research. ${ }^{3,21}$

The total number of RBC varied within the physiological intervals in relation to both experimental groups. There were no significant differences between the results obtained for vicryl on days 7, 28 and 60 in comparison with the results from the control group. In relation to the total number of RBC in the experimental titanium stapler clips group, significant differences were found on days 7 and 60 in comparison with the control group. The HCT results in both experimental groups are compatible with the results obtained for RBC.

From the analysis of the results obtained for HB, it was noticed the obvious undesirable effect of the surgical closure of the appendiceal stump in both experimental groups, in the sense of mildly lower values in relation to the control. The results were found to be significant at $p<0.05$ in all the animals in the second experimental endoloop vicryl ligatures group, as well as in the titanium stapler clips sub-group on day 28 . The values obtained are at the lower limits of the physiological range, or lower in some sub-groups, which clearly indicates the beginning of hypochromia, in line with similar research by Lelovas et al (2017), ${ }^{22}$ and Bajrić et al (2020). ${ }^{3}$

The MCHC and MCV count parameters varied within the physiological range, but they were also significantly different to the control in all three experimental vicryl groups. The parameter MCV was significantly different in titanium stapler clips sub-groups on days 28 and 60 in comparison with the control results, whilst the MCHC parameter was significantly different in all three titanium stapler clips groups.

This study also monitored the poikilocytotic forms of RBC, and the results support the possible finding of anaemia, or mild hypochromia. That is to say, moderate findings were recorded of hypochromic erythrocytes (annulocytes) in the first experimental group in all three titanium stapler clips sub-groups on days 7, 28 and 60. Also, in the titanium stapler clips sub-group, moderate stomatocytosis was found on day 60, whilst moderate spherocytosis appeared in the stapler group on day 7. The experimental endoloop vicryl ligatures group had strong spherocytosis on day 60 , as well as a moderate target cell result on day 60 . The presence of all these poikilocytotic forms of RBC suggests the possible presence of anaemia.

All other poikilocytotic forms were mildly expressed (0.05 - $3 \%$ ) within both experimental groups, but this finding can be ignored since it is irrelevant due to its small percentage value. Moreover, a small number of these poikilocytotic forms probably occurred as artefacts, by mechanical trauma when creating the blood smear. 


\section{Conclusion}

The results of this study favour the use of linear titanium stapler clips over resorbable single endoloop vicryl ligatures, because a less unfavourable effect was established on the blood cells of the experimental rats with their use. The results obtained indicate the possible occurrence of mild inflammation, post-operatively, but to a significantly lower extent than when using the other techniques mentioned. Also, titanium stapler clips cause the beginnings of hypochromic anaemia post-operatively, but in a significantly lower scope than when using the other conventional methods mentioned.

\section{Acknowledgements}

None.

\section{Conflict of interest}

None.

\section{References}

1. Delibegović S, Simatović M. Hirugija tankog crijeva i crvuljka. In: Delibegović $S$, Krdžalić G, Pašić F, eds. Hirurgija/Kirurgija. Sarajevo: Dobra knjiga-UEHBH; 2020. p. 499-513.

2. Delibegovic S, Katica, M, Latic F, Jakic-Razumovic J, Koluh A, Njoum MTM. Biocompatibility and adhesion formation of different endoloop ligatures in securing the base of the appendix. JSLS 2013;17:543-8.

3. Bajrić A, Katica M, Katica A, Smajović A, Sivić M, Rukavina R,et al. Assessment of hematological parameters after laparoscopic appendectomy using conventional procedures on rats. Veterinaria 2020;69(3):165-73.

4. Delibegovic S, Iljazovic E, Katica M, Koluh A. Tissue reaction to absorbable endoloop, nonabsorbable titanium staples, and poly-mer hem-o-lok clip after laparoscopic appendectomy. JSLS 2011;15:70-6.

5. Kavic MS, Kavic SM, Kavic SM. 2012. Laparoscopic appendectomy. In: Kavic MS, Nezhat C, Winfield H. eds. Prevention and management of laparoendoscopic surgical complications. 3rd ed. Miami, FL, USA:SLS; 2012.

6. Soper NJ, Scott-Conner Carol EH, eds.The SAGES manual Vol. 1. Basic laparoscopy and endoscopy. New York: Springer-Verlag; 2012.

7. Delibegović S, Katica M, Koluh A. Formation of adhesions after laparoscopic apedenctomy. In: Marmo AS, ed. Appendicitis. New York: Nova Science Publisher; 2014. p. 207-217.

8. Horzić M, Salamon A, Kopljar M, Skupnjak M, Cupurdija $\mathrm{K}$, Vanjak D. Analysis of scores in diagnosis of acute appendicitis in women. Coll Antropol 2005;29(1):133-8.

9. Khan MN, Davie E, Irshad K. The role of white cell count and c-reactive protein in the diagnosis of acute appendicitis. J Ayub Med Coll Abbottabad 2004;16(3):17-9.

10. Gulzar S, Umar S, Dar GM, Rasheed R. Acute appendicitisrole of clinical examination in making a confident diagnosis. Pak J Med Sci 2005;21(2):125-32.

11. Shoshatari MHS, Askarpour S, Alamshah M, Elahi A diagnostic value of quantitative CRP measurement in patients with acute appendicitis. Pak J Med Sci 2006;22(3):300-3.

12. Kamran H, Naveed D, Nazir A, Hameed M, Ahmed M, Khan U. Role of total leukocyte count indiagnosis of acute appendicitis. J Ayub Med Coll Abbottabad 2008;20:70-1.

13. Baptista ML, Bonsack ME, Felemovicius I, Delaney JP. Abdominal adhaesions to prosthetic mesh evaluated by laparoscopy and electronic microscopy. J Am Coll Sur 2000;19: 271-80.

14. Kosan M, Gonulalan U, Ozturk B, Kulacoglu S, Erguder I, Akdemir 0, et al. Tissue reactions of suture materials (polyglactine 910, chromed catgut and polydioxanone) on rat bladder wall and their role in bladder stone formation. Urol Res 2008;36:43-9.

15. Spahić E, Katica M, Jogunčić A, Katica A, Hasić S. Impact of temperature and the length of exposure on morphological characteristics of erythrocytes in antemortem and postmortem analysis: Experimental study on Wistar rats. Kafkas Univ Vet Fak Derg 2020;26(6):771-6.

16. Katica M, Janković $O$, Tandir F, Gradaščević N, Dekić R, Manojlović M, et al. The effects of calcium aluminate and calcium silicate cements implantation on haematological profile in rats. Kafkas Univ Vet Fak Derg 2020;26(3):427-34.

17. Katica M, Seho-Alić A, Čelebičić M, Prašović S, Hadžimusić N, Alić A. Histopathological and hematological changes by head abscess in rat. Veterinaria 2019;68(3):151-6.

18. IBM Corp. Released, 2016. IBM SPSS Statistics for Windows, Version 24.0. Armonk, NY: IBM Corp.

19. Hanke PR, Timm P, Falk G, Kramer W. Behavior of different suture materials in the urinary bladder of the rabbit with special reference to wound healing, epithelization and crystallization. Urol Int 1994;52:26-33.

20. Katica M, Delibegović S. Laboratorijske životinje Osnovne tehnike eksperimentalnog rada. Sarajevo: Dobra knjiga; 2019. p. 41-62.

21. Kampfmann I, Bauer N, Johannes S, Moritz A. Differences in hematologic variables in rats of the same strain but different origin. Vet Clin Pathol 2012;41(2):228-34.

22. Lelovas P, Stasinopoulou M, Balafas E, Nikita M, Siskos N, Kostomitsopoulos N. Valuation of three different anesthetic protocols on complete blood count and biochemical parameters on Wistar rats. J Hell Vet Med Soc 2017;68(4):587-98. 